\title{
Societal marketing concept and spirituality in the workplace theory: Finding the common ground
}

Anselmo Ferreira Vasconcelos ${ }^{1}$

\begin{abstract}
This paper suggests that there exist many theoretical linkages between the societal marketing concept (SMC) and spirituality in the workplace (SWP) theory. Thus, it is reviewed the literature of both SMC and the emerging field of SWP theory in order to find unexplored commonalities between them. As a result, it acknowledges that SMC broached a new perspective in marketing discipline regarding that it added sizeable social and ethical responsibility to the marketer's role. Most importantly, it posits that the common ground between SMC and SWP theory is, in large measure, the moral reasoning. Overall, this study expands McKee's work (2003) on theoretical intersections between marketing and the spirituality philosophy or paradigm. Rather, it proposes that there is a clear evidence of theoretical overlapping in some constructs, namely, employees, work, workplace, quality of life, ethics, corporate citizenship, and social responsibility. In addition, it is also proposed that SMC-driven organizations are poised to embrace an overall spiritual orientation - whether they have not already done it.
\end{abstract}

Keywords: employees, work, ethics, quality of life, social responsibility, and corporate citizenship.

\section{Resumo}

Este artigo sugere que existem muitas ligações teóricas entre o conceito de marketing societal (CMS) e a teoria da espiritualidade no local de trabalho (EAT). Assim sendo, procede-se à revisão de literatura de CMS e do emergente campo da teoria EAT visando-se identificar pontos comums ainda inexplorados. Como resultado, esse trabalho sustenta que o CMS trouxe novas perspectivas para a disciplina de marketing, considerando-se que ele acrescentou considerável responsabilidade ética e social para a atividade do marketing. Mais importante ainda, sustenta que o elo comum entre a CMS ea teoria EAT é, em larga medida o raciocínio moral. Considerando globalmente, este estudo expande o trabalho McKee (2003) sobre as interseções teóricas entre o marketing ea filosofia ou paradigma da espiritualidade. Mais precisamente é proposto que existe uma clara evidência de sobreposição e/ou convergência entre as duas teorias envolvendo alguns construtos: a saber: empregados, trabalho, local de trabalho, qualidade de vida, ética, cidadania corporativa e responsabilidade social. Além disso, além disso, é também proposto que as organizações inclinadas a adoção do CMS estão prontas para absorver uma orientação geral à espiritualidade - se elas já não procederam tais mudanças.

Palavras-chave: empregados, trabalho, ética, qualidade de vida, responsabilidade social e cidadania corporativa. 


\section{Introduction}

As a result of recent corporate scandals, contemporary organizations as a whole are being painstakingly scrutinized by society. After all, several pillars of modern capitalism such as transparency, customer satisfaction, fair profit, and respect for law, to name a few, are shaken up due to executives' misconduct and misbehavior. In this regard, it is worth remembering that some of them were jailed, like the Mitsubishi Motors' former president and 10 other senior leaders, because of charges related to systematic suppression of vehicle defects (LENNICK; KIEL, 2005). Thus, some questions must be addressed: Why does such a thing still happen? Why do some very well trained executives accept to be involved in such events despite the widespread ethical concerns and management teachings? It is hypothesized here that these events only prevail on corporate settings where wisdom is either scarce or when it does not exist. In other words, where this value has not been recognized and legitimized as vital to organization success (GUILLORY, 2001).

It is not an exaggeration to say that organizational environments such as those above described tend to be fueled by the greed and voracity of their decision-makers (i.e., probably dispirited ones) and, as a consequence, their corporate actions tend to reverberate such kinds of deviances. In contrast, there exist work settings where the providing of meaning and value (that is, not only economic meaning and value) to society prevails. In effect, this post-modern era is calling for more responsible and conscious companies. In this sense, Gioia (2003, pp. 436-437) suggests that corporate leaders and investors should think broader by putting into perspective societal and even global impacts of their decisions.

In fact, individual and societal concerns over environmental issues are apparently increasing (STRAUGHAN; ROBERTS, 1999). Therefore, organizations' marketing strategies need to be redesigned in order to incorporate such concerns and this initiative would mean a considerable advance in business arenas given that not only companies' needs would be fulfilled. Further, other groups' needs should be appropriately addressed as well. Rather, marketing policies should bridge the gap between companies and society in a broader sense. Based on this perspective, Handelman and Arnold (1999), building on Drumwright (1994; 1996), referred to the enlarging role of marketing activities by incorporating a social dimension and/or noneconomic criteria. Kotler (1997), in turn, refined the societal marketing concept (SMC, KOTLER, 1972) by suggesting that the companies should balance their profit needs, consumers' satisfaction, and public interest. According to Abratt and Sacks (1989), under such a concept, the basic goal of a business enterprise - its long-term survival and profitability - would be maintained and organizations that adopt it most likely would be the ones that would benefit society overall (ABRATT; SACKS, 1988). In a similar view, Lee and Sirgy (2004, p. 48) argue that the SMC and its effectiveness are held by offsetting the demands between firms and their stakeholders. Admittedly, the SMC implies the adoption of the very ethical ramifications or, more specifically, in feelings and concerns relating to do something good. Taken together, one can infer that by employing such an approach, one would be focusing on more than just material interests.

In a related vein, the emerging field of spirituality in organizations has been advocated to be beneficial for organizations while encompassing societal, organizational, and employee levels (MOORE; CASPER, 2006). More specifically, Mitroff (2003, p. 191) argue that a spiritual-oriented organization do not produce dangerous or shoddy products, abuse employees, deny the bad consequences derived from its products and services provided to society, among other things. In effect, as suggested by Sirota, Mischkind, and Meltzer (2005, p. 141; emphasis in the original), "Indeed, employees want their companies to do very well and a lot of good." Accordingly, it is very pertinent to mention McKee's (2003) pioneer work that found similar theoretical 
dimensions between marketing and spirituality philosophy or paradigm. Rather, he mapped out some intersections between the processes of supply and demand level. In this sense, it is worth remembering that spirituality in the workplace (SWP), at the individual level, is seen as a multidimensional construct associated, among other things, with social interaction and relationships (BOYLE; HEALY, 2003). Therefore, the core assumption is that individuals desire to do their best and help others to do the same (ROSENTHAL; BUCHHOLZ, 2004). Further, the expression of one's own spiritual ideals and values in the workplace (KOMALA; GANESH, 2007, p. 124) could be seen as a mechanism that enacts integrity, motivation, and job satisfaction (CAVANAG; BANDSUCH, 2002). However, at the organizational level, spiritual-driven firms are encouraged to focus on both the quality of life of organizational-members and the society as a whole (SHEEP, 2006). In fact, Cavanagh et al. (2004, pp. 122-124) note at least five developments closely related to spirituality in organizations, namely, the human relations movement, the stakeholder movement, the social responsibility movement, the business ethics movement, and religious support groups.

Therefore, the purpose of this paper is to explore other points of theoretical overlap between marketing discipline - with more emphasis in SMC - and SWP theory in order to deepen and clarify even more McKee's (2003) study. Our major assumption is that the level of theoretical development made by these theories upon some common constructs is similar. Overall, we believe that such comparison is necessary and important because both theories act apparently toward the same ends - that is, the betterment of people's lives - although employing different approaches that deserve to be examined. Thus, in the section that follows, we will review the SMC literature. Next, we examine both SWP and SMC theoretical communalities. Lastly, some suggestions for future research and conclusions are presented.

\section{The societal marketing concept}

Firstly, research shows that SMC is not fully ingrained on organizational settings despite it has been taught in business schools for decades. In effect, it would be fair to recognize some convincing initiatives toward that direction. For example, Johnson \& Johnson with the Tylenol adulteration in the early 90s that caused to death of 8 consumers in which this company lost near US\$ 240 millions to withdraw the product from the market (KOTLER; ARMSTRONG, 2003) in order to preserve its customers' lives. Ben \& Jerry's and The Body Shop also deserve to be cited as fruitful efforts toward SMC (KOTLER, 1997; KOTLER; ARMSTRONG, 2003; WARD; LEWANDOWSKA, 2005). Additionally, one could mention the McDonalds' initiative in launching a lighter menu in order to be in tune with consumers' healthier habits, at least in Brazilian market (GRANGEIA, 2003), irrespective of potential constraint laws. Dos Santos (2009), in turn, examined the advantageous results of SMC applied into a South African retail chain that benefited all stakeholders. Another company studied by Gull and Doh (2004) that has acted in a respectful way is AES, given that it has been congruent with its integrity, fair, fun provider, and socially responsible business view. Therefore, it is undeniable that SMC broached a new perspective in marketing discipline regarding that it added sizeable social and ethical responsibility to the marketer's role.

Secondly, one cannot assert that SMC has ever received full attention by the decision-makers and marketers given that it has not been universally accepted (COLLINS, 1993), even in business sectors where it should be undoubtedly applied. One clear example of this lack of orientation is the troubled painkiller Vioxx manufactured by Merck Sharp \& Dohme laboratory. This product has been regarded as harmful for patients' health considering that it could cause coronary diseases. Indeed, the company was condemned to pay US\$250 million for a former patient's widow in USA. Other case in point that has been cited by worldwide business 
literature where societal concerns were not properly regarded involves Nike's affair in 1995. That time the company was charged with making business with Asian suppliers that used to hire labor children to work in their plants. There was another shameful affair involving Wal-Mart Stores and its employees. The company was ordered by California jury to pay US\$ 172 million in damages for failing to provide meal breaks to nearly 116,000 hourly workers as required by the state law. Furthermore, the suit, filed on behalf of employees of Wal-Mart and Sam's Club stores in California, argued that the chain violated state law more than eight million times (STEIN, 2005). More recently, Fraga (2009) remarks the wave of tricky functional foods manufactured by larger companies. In Brazil, Telefonica, for example, has been consistently showing lack of respect in the relationship with its customers. Similarly, research shows unethical behavior in organizations that deliberately reduce the weight and/or amount of their products, yet maintaining the original prices (see, for example, MENDES; VIEIRA; CHAVES, 2009). These are some notorious examples signaling that the moral component is yet underestimated by many organizations.

Nonetheless, SMC has obtained little theoretical development since the early 1970s, as well as it has produced low impact on the traditional principles of marketing theory (CRANE; DESMOND, 2002), yet it has become imperative in contemporary marketing policies due to the growing corporate social responsibility pressures. In fact, Crane and Desmond suggest that, in spite of the solid moral terrain in which SMC is anchored, "the concept raises some fundamental, perhaps irreconcilable difficulties" (2002, p. 549). In our view, this sort of questioning outlines the challenges that the majority of organizations will likely have to face from now on. Therefore, firms that adopt the SMC tend to receive more favorable publicity (such as the above mentionated case of Johnson \& Johnson), enhanced corporate image (CHATTANANON et al., 2007), customer respect, and the recognition of stakeholders.

On the other hand, it must be acknowledged that SMC appears to be both negatively correlated with performance and moderated by competitive hostility (WARD; LEWANDOWSKA, 2005, p. 670), despite the evidence that it is more appealing in terms of moral commitment. In addition, SMC seems to be more effective when employed to maintain business environments rather than reducing the turbulence or hostility in business ones (WARD; LEWANDOWSKA, 2008). However, anecdotal evidence shows that firms less prone to employ SMC take a risk of apologizing to the society as General Motors did recently in an ad: "At times we violated your trust by letting our quality fall below industry standards and our designs became lackluster". (Aumotive News, 2008)

Bell and Emory (1971, apud COLLINS, 1993, p. 3) pointed out that SMC-driven organizations will likely avoid entering into markets which could impair consumers in the long-run. Thus, the adoption of SMC encourages organizations to operate in a wiser manner, because they "will not only gain competitive advantage over who do not, but are more likely to survive in the long term with the support and approval of society" (COLLINS, 1993, p. 3). Having a different perception, Takas (1974) raised doubts about the possibility to juxtapose profitability and societally desirable actions by companies. But in today's business landscape - where societal issues are undoubtedly salient - such concern does not make sense anymore. To some degree, SMC does not raise new questions anymore, but certainly ones that are still waiting for the right answers and acts. Based on the aforementioned reasoning, we are aligned with Calahorra (1993) who posits that the societal approach in marketing means a new frontier and philosophy from both marketing discipline and management as a whole. Further, it indicates that companies should not turn back anymore to this dimension, whether they want to keep alive. Regardless of the sector they belong to, the societal components are increasingly demanding. 
In light of that reasoning, Kang and James (2007) state that

\begin{abstract}
"Arguably, the well-being of individuals and society can be achieved by the enhancement of positive consequences associated with production and consumption of a product, as well as the limitation and/or reduction of negative consequences associated with production and consumption of a product. The reduction of negative consequences and enhancement of positive consequences should be complementary in the conceptualization of a societal orientation. To this respect, a societal orientation should be concerned with maximizing positive impact of and minimizing negative effects associated with the production and consumption of a product in order to increase the long-run well-being for consumers and society at large." (p. 305)
\end{abstract}

Similarly, Giacomini Filho (1993) ponders that SMC reassures several humanitarian values such as environmental respect and concerning with the well-being and quality of life of children, older citizens, minorities are higher than individual interests and corporate ones. Thus, SMC does not search for new solutions to marketing problems, but it incites organizations to avoid failures in dealing with vital issues related to the implementation of a marketing strategy that could eventually collide with a societal value. As we will see in the next section, SMC encompasses many concerns that have also been investigated by the emerging field of SWP. Such a perception suggests an area of theoretical overlapping (see Figure 1) whereby some constructs have been explored by both theories. As McKee (2003, p. 64) proposes, the organizations that are concerned with ethical and humane practices should look at spiritual perspective.

Figure 1 - Interfaces between societal marketing concept and spirituality in the workplace theory

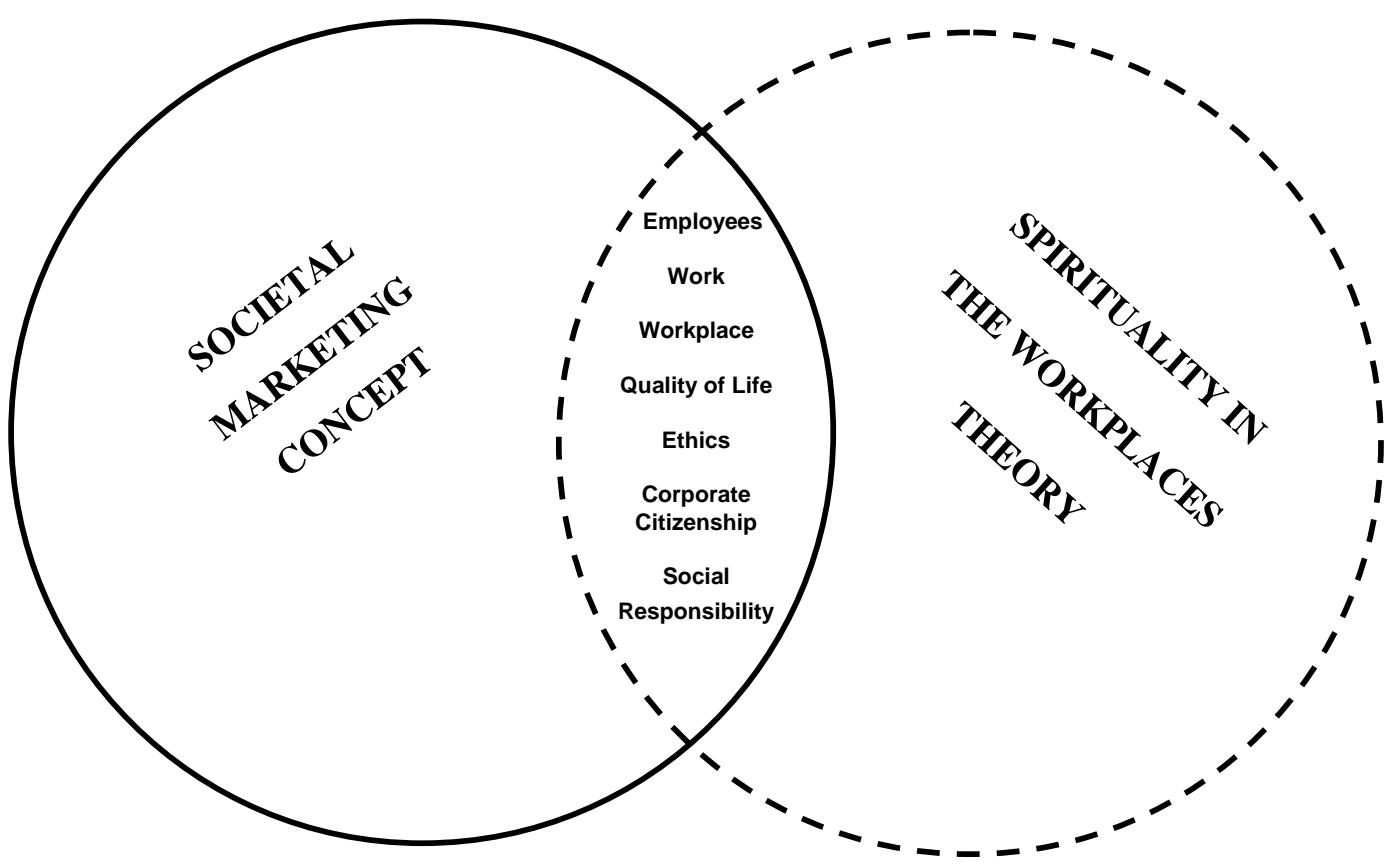

Font: Author 


\section{The commonalities between SWP theory and SMC}

Spirituality is a topic that has drawn interest in managers and researchers worldwide. On the face of it, there have been a substantial number of conferences, articles, books, specific websites, and courses that have shaped it as a new dimension of management (GARCIA-ZAMOR, 2003a; GIACALONE; JURKIEWICZ, 2003; HOWARD, 2002; TISCHLER, 1999). In fact, the quest for postmaterialist assets wherein spirituality gives unmistakable signals of being one of them (GIACALONE; JURKIEWICZ, 2003), is a consequence of harmful management practices for employees' inner life (i.e., spiritual needs). Thus, it is worth remembering that "Spiritual human needs are fulfilled by a recognition and acceptance of individual responsibility for the common good, by understanding the interconnectedness of all life, and by serving humanity and the planet. Therefore, when one speaks about bringing spirituality into the workplace, he/she is talking about changing organizational culture through the transformation of leadership and employees so that humanistic practices and policies become an integral part of an organization's day-to-day function." (GARCIA-ZAMOR, 2003b, p. 328)

Such a view has apparently encouraged people to adopt a more active role in the world they live in by engaging them in meaningful activities and to protest against all institutions that disrespect or inflict the societal issues. In this sense, the simple fact of being associated, for example, with an organization - even though performing the role of an employee with lesser duties and responsibilities - that is not well-intentioned can cause stress and inner discomfort. People that are looking for something more valuable would likely feel, as posited by Pfeffer (2003, p. 33), that "the mere accumulation of values or assets - which will invariably be left behind at death anyway - does not provide a compelling rationale or motivation to inspire people."

Similarly, the majority of transformations that are currently underway have also changed perceptions, demolishing old beliefs, affecting people's workplace lives, among other things. As a consequence, we are living in a time where the topic of spirituality in organizations has been apparently welcomed. In a related vein, Gozdz (2000) notes that machine-concepts such as logical-positivist, rationalism, and empirical assumptions, considered as by-products of Enlightment Era and foundations of orthodox science, have been losing ground. Gull and Doh (2004) argue, in turn, that in the spiritual oriented organizations, positivism, materialism, determinism, and egoism do not support managerial decisions. In addition, the notion of nonmaterial values has gradually penetrated within the general system of orientation, triggering other perceptions and beliefs such as the pursuit of not just profit goals. Accordingly, it is feasible and desirable to set a broader set of objectives that goes beyond the own self-interests, wants, and desires so as to support a more creative and self-fulfilling state that can be beneficial to humankind.

Although some features such as selfishness, greed, and competition are still present in the human soul, by contrast, there is ample evidence that things are changing. Thus, contemporary issues such as growing unemployment rate, water and air pollution, environmental destruction, terrorism, violence, poverty, increasing inequalities, globalization problems, and many other things that have affected the planet help us understand that our lives are closely intertwined. In this regard, the spiritual paradigm - that is, the thought or belief that life also encompasses other concerns and dimensions than just material ones - reminds us that we should be less self-centered, materialist-driven, and more committed to do something good without any personal interest. At the organizational level, such a vision could be construed by embracing a nobler mission like serving humankind (stakeholders) in more respectful, honest, and healthful ways, and getting the fair profit for it. Indeed, Pfeffer (2003) remarks that firms toward the adoption of spirit tenets strive to treat their workers with dignity and respect, not simply as economic agents or factors of production. 
Although the metrics of that proposition are not clearly defined, the general premises that hold SWP theory developing vis-à-vis to actual organizational practices as proposed by Sass (2000) could be useful. Nonetheless, Mitroff (2002) is the opinion that an organization to be labeled as spiritual-driven is one in which its executives, managers, and workers try to enact spiritual and ethical principles in their daily tasks. In a related vein, Biberman and Whitty (1997) pointed out that organizations that are inspired by a spiritual paradigm tend to exhibit: flatter organizational structures, greater openness to change, higher levels of intra-organizational interconnectedness and cooperation, and widespread empowerment of workers irrespective of their levels. Such companies, according to them, would not adopt the notion of self-preservation at all cost, but they would be focused on the ecological and environmental issues and more concerned with meeting the internal and external customers' needs.

It is important to recognize that those perceptions are also explored by SMC. In our view, SMC fits perfectly into a broader SWP theory framework or higher-order construct. Put another way, the societal marketing policies is likely to be carried out by companies where the SWP theory is being incorporated on their business activities. Again, we argue that both marketing and spirituality are interconnected or integrated through some constructs and through the literature review we distinguish seven ones (see Table I). In the next section, we discuss (1) how these linkages have been explored by both streams of researchers and (2) attempt to summarize them in a broader frame.

Table 1 - Societal Marketing Concept and Spirituality in the Workplace Theory Overlaps

\begin{tabular}{c|c|c}
\hline \hline $\begin{array}{c}\text { Societal Marketing } \\
\text { Concept }\end{array}$ & Constructs & $\begin{array}{c}\text { Spirituality in the Workplace } \\
\text { Theory }\end{array}$ \\
\cline { 1 - 1 } $\begin{array}{c}\text { Level of Theoretical } \\
\text { Development }\end{array}$ & Employees & $\begin{array}{c}\text { Level of Theoretical } \\
\text { Development }\end{array}$ \\
High & Work & High \\
High & Workplace & High \\
Low & Quality of Life & High \\
High & Ethics & Low \\
High & Corporate Citizenship \\
Moderate & Social Responsibility & Moderate \\
High & & High \\
\hline \hline
\end{tabular}

Font: Author 


\section{The Employee Component}

There is a widespread belief that employees play a key role in any organization success. In the field of marketing, the same reasoning has prevailed, irrespective of the sector that a company belongs to. After all, employees (people, partners, associates, internal customers or whatever the name they are labeled) are responsible to deliver the organization's promises. In this light, it is imperative that they be aligned with their employers' interests so as to keep things well-functioning. To Bhattacharya and Korschun (2008, p. 114) marketing thought should be expanded and also aimed at improving the welfare of organization's employees by "tailoring employee compensation and health benefits to the needs of individual employees or employee segments." Relatedly, Peter F. Drucker (1998) had wisely recognized that the task of management employees became increasingly a marketing duty. Therefore, the likelihood of a firm's external marketing activities to be efficient without caring about its internal market needs are near zero in the current business landscapes.

As a consequence, a persuasive way to value employees was suggested by Judd (2003) when he proposed the inclusion of a fifth $P$ within the marketing mix repertoire (i.e., people-power), regarding that every employee contributes to the mission of creating customer-value. Similarly, Pfeffer and Veiga (1999) warned that managers should indeed consider that people constitute the organization most important asset. In a related vein, Rosenbluth and Peters (1998) advocated that employees serve as a company's differentiator and sustainable competitive advantage. However, the more appropriate mechanism to recognize people's organizational value and assure their commitment with the organizational objectives seems to be through well-designed and implemented internal marketing policies (IMP).

In this sense, Ahmed and Rafiq (2003) propose that internal marketing strategies must indicate convincingly to employees that the organization values them. Czaplewski et al. (2001), in turn, claim that such efforts mean a basic procedure toward building employee capabilities and motivation. In doing so, one could assert that, at the basic level, it would symbolize that a company is both seeking to enhance its performance and trying to contribute to a better world. In light of the integrated process (internal and external) that permeates all relationships of a company, it is reasonable to expect that SMC be equally held by IMP whereby workers' wellbeing - or even happiness in the workplace, whether one regards IMP in a higher degree (Vasconcelos, 2008) is a relevant organizational goal as well.

On the other hand, the same ends above cited are pursued by the SWP orientation. Congruent with this view, Krishnakumar and Neck (2002) state that it makes employees feel complete because it encompasses their work life. These authors argue that SWP is helpful in the spheres of "creativity, honesty and trust, personal fulfillment, and commitment which will ultimately lead to increased organizational performance" (2002, p. 156). Similarly, Garcia-Zamor (2003a) suggests that the organizations operating under such orientation believe that it creates a more humanistic work environment where win-win situations are developed and encouraged for both employees and employers.

Parboteeah and Cullen (2003) highlight, for their part, that spiritualized organizations have been benefited given that the employees tend to be more satisfied and happy with their work which can culminate in better organizational results. Following the same line of reasoning, Jurkiewicz and Giacalone (2004) believe in the positive impact that is caused on both employees and companies' performance by means of SWP theory. Moxley (2000) warns that if firms are expected to take advantage of their employees' energies and talents, then it is crucial that they allow the spirit theme to be developed in organizational settings. Lastly, Howard (2002, p. 240) suggests that "Talking about spirituality in relation to our work might encourage more individuals to 
explore their spirituality, and that may lead to wider benefits in organisational life and in society as a whole." Therefore, the literature clearly shows that the level of relatedness of employees (people) construct in both SMC and SWP theories is very high.

\section{The Work Component}

The work aspect is inserted into this discussion considering that it is a dimension strongly intertwined with employee motivation. Stated differently, work is a pivotal component of the human beings' lives because it embraces a mechanism of paramount importance whereby people generally build their identities. Despite the current chaotic frame, intelligent organizations employ their strengths, capabilities, and resources toward attending to the highest expectations of their people at work. Whether workers constitute, indeed, the most important firms' asset, then it would be normal to expect that organizations provide meaningful and richer work to them. Accordingly, one of the best ways to exhibit such a concern is by designing jobs as products.

In fact, Berry (1981) conceived of that job-products should be crafted in a manner that could encourage higher involvement and performance, and, by extension, discourage quitting. More specifically, "designing jobproducts that attract, develop, motivate, and retain employee-customers demand sensitivity to their aspirations, attitudes, and concerns" (BERRY; PARASURAMAN, 2000, p. 188). Similarly, Rafiq and Ahmed (2000) suggest the incorporation of a set of features on the job that are demanded by prospective employees. Flipo (2000), in turn, remarks that IMP, to be efficient in terms of job attractiveness, should address the creation of perceived value - just as one does with external customers - that sometimes implies in little or no costs to the organization. On the other hand, Ahmed and Rafiq (2003) bluntly state that employees have both rational and emotional needs and internal marketing actions must peruse them in order to create packages of solutions that satisfy their needs fully. Rather, it is proposed that the needs of workers should be met as much as possible by all organizations, especially when one takes into account the hardship times that people are living today, even in the organizational settings. Such propositions are wiser ones and have the advantage to go beyond of focusing only on the task requirements established to the job. Additionally, it will likely help the organizational effort toward alluring and maintaining the best employees. Taken together, we realize that when internal marketing tools are pinpointed to build job as products, one can improve substantially people's work lives. Therefore, it is assumed here that under SMC, work is a critical variable that must be treated carefully especially through IMP - in order to motivate employees to do their best.

SWP researchers, in turn, offer some pertinent comments about the construct of work that is worth being examined here. Trott (1996), for example, posited that the SWP is derived from people's growing desire and/or search for greater meaningful and purpose in work. Of course, it is premised on the belief that work has the power to generate the feelings of self-fulfilling and wholeness on people. In fact, it is inconceivable to think in our lives detached from some kind of work. As Trott rightly remarked "Not to work is devastating" (1996, p. 1). But a job can be, in contrast, a dreadful experience when people are on the edge of the organizations' interest. Moxley (2000) refers to it as dispiriting jobs when they do not fuel people's talents and drain, at the same time, their energy like the burnout symptoms that can be noted all but everywhere.

Moreover, Wrzesniewski (2003) notes that work can be a source of many feelings and perceptions such as pain, drudgery, boredom, or, by contrast, joy, energy, and fulfillment, or a blend of it all. However, whether the majority of organizations are not yet able to provide just positive job experiences to the internal customers, at least in the marketing and SWP theories, work construct has been highly explored. 


\section{The Workplace Component}

The workplace component is a natural and undisguised extension of work dimension. Although work itself can enact people's identities and self-fulfilling, as it has been explored in this paper, it cannot be manifested in places where human capital development is not a priority. Today's workplaces have paradoxically produced higher levels of stress and, accordingly, the work life has substantially deteriorated. Evidence shows that this corporate disease has spread throughout in all kinds of organizations. In addition, there have been clear signals of employees' suffering from overwork. As a result, Mudie (2003, p. 1266) notes: "Rather than loyalty, commitment, efficiency and quality, organisational life offers up the potential for resentment, discontent and disaffection." Obviously, these things can potentially generate the feeling of unhappiness in the workplace. In supporting of this line of reasoning, Moxley (2000) states that the majority of people come back home drained, deenergized, and used up for the sake of their jobs routines, and, as a detrimental effect, society has lost vitality as well as energy that it desperately needs.

In contrast, some organizations have already understood that work is a core dimension of people's lives, and inspired by the spiritual thought, they are transforming workplaces into providers of more humanized experiences. As King and Nicol (1999) suggested, much of the spiritual odyssey take places inside the workplaces. In other words, the workplace can be a place where people are in search for creating a valid experience or journey around their work; a place where one can find personal expression and accomplishment (DEHLER; WELSH, 2003). In fact, Elm (2003) notes an increasing trend in both organizational settings and organizational research toward these directions. Similarly, Buchholz and Rosenthal (2003) believe that SWP can ease to establish moral values in the workplace and to stand up for what one believes, as well as to help shape a wiser notion in which the life as a whole is sacred. Seeing SWP under a transformational movement, Eisler and Montuori (2003) argue that there is increasing evidence that it contributes to a more humanized workplace thereby organizational structure tends to be more productive, flexible, and creative. Therefore, in the SWP theory, the workplace variable has been highly developed.

As for the marketing approach, organizations have not apparently applied IMP in a way that wows and engages internal customers as much as they should. In this sense, Bell et al. (2004) point out that the organizational support must be provided (1) in the form of resources to employees in order to they can carry out their responsibilities and, more importantly, (2) by creating a work environment in which they can feel better about their jobs and the outcomes that are expected of them. Admittedly, these procedures help prevent that they look for another job elsewhere. On the other hand, Gavin and Mason (2004) propose that

"When a workplace is designed and managed to create meaning for its workers they tend to be more healthy and happy. Healthy and happy employees tend to be more productive over the long run, generating better goods and more fulfilling services for their customers and the others with whom they interact and do business". (p. 381)

Despite internal marketing be likely the more appropriate management tool to deal with employees' aspirations, needs, and dreams at work (i.e., the most suitable managerial mechanism whereby one can provide job satisfaction), managers and organizations apparently underestimate their strengths by failing to conceive workplaces as source of employee delight and fulfillment. Otherwise, we would have just great places to work for. Thus far, the marketing researchers have paid scant attention to the workplace construct. 


\section{The Quality of Life Component}

Also, there has been a growing awareness about better and healthier products and/or services. In fact, people are recognizing that their health is an asset that must be carefully managed and such concern has created many challenges in many business arenas. Straughan and Roberts (1999) remarked that companies are undergoing great pressure from social groups and law constrains that are affecting their product lines (e.g., formulations, design, and package composition) in such a way that they are constrained to keep abreast of developments in environmental movements. In this regard, the quality of life (QOL) concept is a suitable reaction from organizations that are trying to conform to these forces and pressures. Professor M. Joseph Sirgy from Virginia Tech and his colleagues have hunkered down on QOL philosophy and showing that its tenets can help enhance the organizational creations and, by extension, our lives. Therefore, through QOL approach one would note germane advances in marketing theory as well as in the ethic field wherein it rests its theoretical foundation. According to Sirgy (1996), QOL concept advocates that the task of enhancing the well-being of consumers should be implemented regarding the preservation of the environment. Thus, "Doing no harm is part of the spirit of QOL marketing" (LEE; SIRGY, 2004, p. 47). In addition, QOL has inspired marketing strategies with a broader view in which one tries, among other things, to cultivate and maintain a brighter corporate image toward stakeholders (AMATO; AMATO, 2002).

Lee and Sirgy (2004) posit that QOL marketing is grounded on the SMC, although it has also been imbued by relationship marketing thought and stakeholder theory. However, QOL can be seen as a byword for progress regarding Lee and Sirgy's opinion that it focuses on the need of establishing and reinforcing long-term relationships between organizations and their stakeholders and, at the same time, integrating ethical and socially responsible concerns into marketing programs. These guidelines have been gradually introduced in marketing theory. In doing so, they might help organizations to improve the products and deliver quality of life to consumers. Furthermore, it is believed that QOL marketing strategies encourage trust, commitment, benevolence, and satisfaction on consumers. Moreover, the adoption of QOL marketing implies to achieve not only companies' financial goals, but societal outcomes likewise.

By contrast, some authors express disagreement with that orientation. Miles and White (1998) argued, for instance, about the dangerous of QOL marketing be adopted as a pattern by all organizations. In their view, the general outcomes would be less attractive and customer would likely pay higher prices for less selection, and employees, by extension, would earn less salaries. Further, in the macro level one would obtain lower investments rates and probably dissatisfying economic growth. For their part, the communities, according to this reasoning, would face job losses and deteriorating tax bases. Under this very pessimistic view, QOL marketing could be regarded as socially irresponsible. Nonetheless, it is worth remembering the popular saying which advocates the notion that there is no free lunch. From this point of view, the society will have to choose therefore which price must be paid. Regardless of it, we speculate that a higher price has already been paid; rather, there is no empirical evidence that QOL marketing strategies have been de facto adopted by organizations in an optimal level (cf., Fraga, 2009). However, for the purpose of this study, the construct of quality of life has been highly explored by marketing theorists. 
On the other hand, QOL orientation has been practically unexplored by SWP researchers. We surmise that it is derived from the fact that research about spirituality on organizations has barely started (Heaton et al., 2004). Nevertheless, the spiritual thought can be noted - even in the organizational level - by the practice of organizational virtues and acts, positive attitudes, and respectful relationships between organizations and their stakeholders.

In this sense, Ashar and Lane-Maher (2004, p. 253) posit that "When virtues, ethics, emotions, and intuition are part of the organization's behavior and policies, the organization is spiritually oriented." Further, under such business orientation one does the good for its own sake. Accordingly, Biberman and Whitty (1997) predicted that - and we are aligned with it - growing number of organizations will shift to the adoption of spiritual paradigm in the future. Therefore, there is no reason to believe that QOL philosophy, given its importance, will not be investigated from a spiritual standpoint sooner.

\section{The Ethical Component}

On the other hand, the corporate world has been showing great examples that the ethical lessons are not fully learned by managers, yet it has been taught in all business schools around the planet since 1980s. The events involving important companies in different countries have clearly showed that the economic concerns surpass the non-economic ones in large measure. In doing so, firms very often take the risk of misbehaving and, by extension, tarnishing their reputations. However, the ethical component remind us that: (1) misbehavior is not tolerated anymore; (2) its tenets must be regarded in all managerial decision processes; and (3) the organizations that do not fit into a ethical world do not deserve to be part of it.

Both Marketing scholars and SWP researchers have showed considerable interest on this topic. Singhapakdi et al. (2001), for example, argue that the ethical issue and social responsibility are themes increasingly relevant in the context of global business. According to Hunt et al. (1989, apud SINGHAPAKDI et al., 2001), when the ethical standards are internalized by organizational members, organizational success tends to be enhanced. Smith (1995) highlighted the ethical trend in public and private life encompassing areas such as politics, education, health, and business. In contrast, D'Angelo (2003) remarks that marketing activities have been suffering criticism, distrust, and doubts due to principles and practices that collude with ethical and moral aspects. Indeed, what is advertised by marketing activities is not always the truth. Relatedly, Cohen (2001, p. 580) appropriately states that "Universal moral principles do not require that marketers become social reformers". But if they at least mirror on them, the world would be certainly better-off. Therefore, in this era of ethical behavior requirements, marketing managers - like or dislike it - are in charge of respecting and caring about the welfare of those affected by their decisions. Further, when the ethical component is present in a firm marketing actions, it should be construed that SMC is somewhat leveraging on its running. Nonetheless, research indicates that there remain salient misunderstandings about this point (see, for example, MENDES; VIEIRA; CHAVES, 2009).

As for the SWP theory, by contrast, one could assert that ethic construct is one of its core pillars. When ethical tenets are incorporated by organizations, they are generally constants and help function as building blocks (ANDERSON, 1997, p. 27). More exactly, to Gull and Doh (2004) organizations that are inspired by spiritual principles avoid ethical misconduct. Ingersoll (2003) notes that ethical sense derives from people's beliefs in an absolute or divine power; additionally, a healthy organization allows the employees to practice it on workplaces. Similarly, Pauchant (2002) remarks that there exist other indicators suggesting that increasing amount of employees and managers want to include ethical and spiritual values in their workplaces. 
Importantly, it stimulates the moral imagination and provides understanding upon many ethical problems that permeate international settings (JACKSON, 1999). Based on these opinions, we argue that SWP and SMC share the same concerns related to the ethic construct. Thus, ethical theme has been highly developed by both theories

\section{The Corporate Citizenship Component}

Notwithstanding corporate citizenship do not pertain to the mainstream of marketing researchers, yet it has been gradually employed as a marketing topic by more advanced organizations. Actually, corporate marketing strategies that aim to be more effective should not refrain from focusing on this perspective as well. There has been increasing pressure on companies requiring that they be more sensitive to other groups and publics than to be just restricted to their consumers and channels demands. Thus, in showing corporate citizenship concerns firms are convincingly demonstrating that they pursue other noble interests than the traditional ones. In other words, this concept enlarges the organization obligations toward of what has been believed to be positive to employees, businesses, and society as whole. In essence, there is a general desire that corporations act decently (HANDY, 1998)

Maignan et al. (1999) found important aspects that reinforce the view above mentioned. It must be emphasized, however, that corporate citizenship is associated with a set of activities and organizational processes that must be put into practices by companies in order to fulfill some social responsibilities such as work-family policies, ethics programs, corporate volunteerism, and even green marketing. Overall, it can be noted in organizations that satisfy the economic, legal, ethical, and discretionary responsibilities required by their stakeholders. Moreover, citizenship approaches are considered to be beneficial in terms of employee commitment, taking into account that the tasks tend to be more enjoyable let alone the feeling of pride that they usually engender.

Corporate citizenship has also been associated as a source of competitive advantage to firms that provide superior value to customers. Second, it is attributed to generate difficulties to be imitated given that companies must be responsive in dealing with a diversified stakeholder demands. Third, it offers multiple applications such as aiming at employee motivation, in advertising in order to improve customer's image of the organization, and in talks with community leaders. Based on industry surveys, Maignan and Ferrell (2001) suggest that corporate citizenship may be applied in both external and internal marketing. These authors believe that it could be a very especial mechanism to sell organizations and their products to employees' audiences. But it is equally reasonable to imagine that some corporate citizenship actions would be welcomed, namely, no layoff policies, employee equity policies, pleasant work aesthetics, among others. Despite this construct has been scarcely perused by marketing researchers, it does not reduce its relevance. As for the spiritual approach to this issue, scholars have basically focused on community aspects. Thus, Gozdz (2000) emphasizes that organizations that aspire to become spiritual places require that they transform themselves as communities of practice.

Many authors (e.g., ASHMOS; DUCHON, 2000; KING; NICOL, 1999; NEAL, 2000) share a similar view wherein SWP emerges as a sense of community where people can establish more profound connections between them by showing things such as respect and genuine care for each other. Overall, it is supposed to create and develop conditions for authentic or healthy relationships eliminating, as a consequence, dysfunctional behavior. 
In sum, at the organizational level, the evidence suggests that there is more room to be explored involving corporate citizenship under spiritual lens. Given that the SWP theory is in its inception, the construct was reviewed here will likely receive more attention in the future. Based on this review, we note that corporate citizenship has been moderately explored in both marketing and SWP theoretical streams. However, whether one regards the increasing societal concerns, one can predict that corporate citizenship is going to play a vital role in business performance sooner.

\section{The Social Responsibility Component}

A few decades ago the major social responsibility of a business was designated to be merely of the economic nature whereby organizations should produce the goods and/or services desired by society and create sustainable economic wealth (CARROLL, 1979, apud MAIGNAN; FERRELL, 2001). By early 90s, such a view had already suffered significant shifts. Carroll (1991, apud CARROLL, 1999, p. 289), for example, refined it when he added that a firm where corporate social responsibilities (CSR) were present "should strive to make a profit, obey the law, be ethical and be a good corporate citizen." The overarching conclusion that underlines this construct is that organizations have not only economic and legal obligations but other responsibilities that go beyond the conventional ones. Nowadays, there is a sizable enthusiasm for this theme that reverberates likewise in the field of marketing (see MAIGNAN; FERRELL, 2004) where it has been employed as a kind of investment in which it is supposed to positively affect the performance of the organization in the long run (VARADARAJAN; MENON, 1988).

Murphy (2004), in turn, makes a timely distinction between the ethics and social responsibility constructs that it is worth exploring here. Whereas ethics generally refers to the individual level, social responsibility is closely linked with the corporate/organizational level. Likewise, Carroll (1999, p. 288) posited that CSR should be seen as "the base point, building block, or point-of-departure for other related concepts and themes, many of which embraced CRS-thinking and were quite compatible with it". Accordingly, one of them is the corporate citizenship construct that was discussed in the earlier section. Focusing on the organizational pragmatism, Maignan and Ferrel (2004) accurately remark that the efforts that have been done by companies in order to be seen as socially responsible. They cite, as part of this group, companies such as British Petroleum that showed an undeniable commitment to natural environment by changing its name to Beyond Petroleum. Following the same line of reasoning, Nike has advertised itself as a firm concerned with responsible business practices, profitability, and sustainable growth. Coca-Cola, other distinguished case, has moved toward responsible corporate governance.

Other companies are seeking for mechanisms that link corporate objectives to social responsibility activities through "the development of citizen advisory panels, public hearings, meetings with community service organizations and participation in community events" (MCALISTER; FERRELL, 2002, p. 692). In doing so, they create a solid image of being concerned with the well-being of others, not just with themselves. Stated differently, these sorts of companies tend to be regarded as serving humankind's interest as well. According to McAlister \& Ferrell, there are a great amount of companies that employ their resources and competencies toward the needs of employees, customers, business partners, community, and society, reaping, in consequence, health financial outcomes.

Of a more specific and noteworthy marketing-like approach, Kotler and Amstrong (2003) argue that social responsibility in marketing is to engender not only pleasant products, but the ones that be, at the same time, beneficial to society. Taken as whole, the arguments above mentioned encapsulate and reinforce perfectly the 
idea of the SMC. Further, they allow us to surmise that whether, on the one hand, those new issues become the task of running the businesses more complex than as usual, on the other hand, they all come to the betterment of society and the planet.

As for the spiritual approach - which it is referred to as a holistic perspective by Heaton et al. (2004, p. 73) - on this topic, one could apply an organizational assessment through the monitoring of strategies that aim to reach and improve the social impact and keep the environmental sustainability. Of noteworthy initiatives are the reports related to organizations that follow the spiritual paradigm through consistent CSR measures such as: Harley Davidson (see CACCIOPE, 2000), Service Master (PFEFFER, 2003), Tom's of Maine (WAGNERMARSH; CONLEY, 1999) to name a few. Thus, in marketing and SWP theories, CSR construct has been highly explored.

\section{Future research and conclusions}

As we have tried to show throughout this paper, SMC is a sort of marketing-orientation that concerns with organization, consumers, and society by means of healthy or environmentally-friends products and services. Although, such approach is exclusively derived from the marketing-like thought, it wisely advocates a general business orientation whereby the well-being of society must be the major purpose of the organizations' efforts. In contrast, SWP theory embraces a more ample and/or multi-level perspective given that it has been postulated to be the fourth organizational wave (WAGNER-MARSH; CONLEY, 1999) or paradigm (DENT, HIGGINS; WHARFF, 2005). Either way, the spirituality at the organization level presupposes that the core of an organizational decision making system is stimulated by setting and pursuing respectable goals and purposes. Overall, we found that several topics that have been explored by both SMC and SWP theory. Despite the marketing mainstream are predominantly toward to the study of consumer behavior and mathematical models, there is room for other approaches that are of great interest to society. More exactly, SMC seems to be the alternative that incorporates this concern given that it preserves the organization's economic sustainability along with the tasks of meeting consumer needs, the well-being of society, and environment preservation (see KANG; JAMES, 2007; KOTLER, 1997; KOTLER; ARMSTRONG 2003).

This paper proposes that the common ground between marketing, that is, SMC - regarding QOL marketing as part of it - and SWP theory is fundamentally the moral reasoning. Another point that deserves some remarks has to do with the assumption that SMC-driven firms are poised to embrace, in our opinion, an overall spiritual orientation, whether they have not already done it. We envision that in this aspect lies a fruitful research avenue to be explored. Moreover, organizations that are enlivened by these managerial orientations tend to be more helpful to our civilization. In other words, they are a sort of progress-minded organizations because they have already understood that their missions, above all, are to do the good to the mankind. Thus, they generally employ their skills and core capabilities in order to attain this very important end.

Indeed, it seems that firms that are inspired by SMC and SWP theory operate in a way that profit and social responsibility fit into their business enterprises very well. In addition, they demonstrate to be interested in making meaningful contributions to humankind's life without sapping the resources of the planet. In this sense, another interesting research stream that deserves to be examined is related to finding out whether managers that work for companies that follow a SMC orientation are also inspired by the spiritual paradigm. On the other hand, constructs such as employees, work, workplace, quality of life, ethics, corporate citizenship, and social 
responsibility are theoretically enriched by both approaches employed here, but there are other ones that could be probed such as relationships, strategies, and goal settings. This investigation shows that some constructs are more inserted into one theoretical domain than the other. However, there is no denying that they can be investigated by both of them.

\section{References}

ABRATT, R. AND SACKS, D. "the marketing challenge: towards being profitable and socially responsible". Journal of business ethics, VOL. 7, NO. 7, PP. 497-507, 1988.

ABRATT, R. and SACKS, D. "Perceptions of the societal marketing concept". European Journal of Marketing, vol. 23 , no. 6, pp. 25-33, 1989.

AHMED, P.K. and RAFIQ, M. "Internal marketing issues and challenges". European Journal of Marketing, vol. 37, no. 9, pp. 1177-1186, 2003

AMATO, C.H. and AMATO, L.H. "Corporate commitment to quality of life: evidence from company mission statements". Journal of Marketing Theory and Practice, vol. 10, no. 4, pp. 69-87, 2002.

ANDERSON, C. "Values-based management". Academy of Management Executive, vol. 11, no. 4, pp. 25-46, 1997.

ASHAR, $H$. and LANE-MAHER, M. "Success and spirituality in the new business paradigm". Journal of Management Inquiry, vol. 13, no. 3, pp. 249-260, 2004.

ASHMOS, D.P. and DUCHON, D. "Spirituality at work: a conceptualization and measure". Journal of Management Inquiry, vol. 9, no. 2, pp. 134-145, 2000.

AUTOMOTIVE NEWS. "The auto industry bailout. GM says it 'disappointed' consumers". Available at: http://www.autonews.com/apps/pbcs.dll/article?AID=/20081208/ANA02/312089881/1018/FRONTPAGE (Accessed on December 10, 2008).

BHATTACHARYA, C.B. and KORSCHUN, D. "Stakeholder marketing: beyond the 4P's and the customer". Journal of Public Policy \& Marketing, vol. 27, no. 1, pp. 113-116, 2008.

BELL, M. and EMORY, C.W. "The faltering marketing concept”. Journal of Marketing, vol. 35, no. 4, pp. 37-42, 1971.

BELL, S.J., MENGÜÇ, B., and STEFANI, S.L. "When customers disappoint: a model of relational internal marketing and customer complaints". Journal of the Academy of Marketing Science, vol. 32, no. 2, pp. 112-126, 2004.

BERRY, L.L. “The employee as customer”. Journal of Retail Banking, vol. 3, no. 1, pp. 33-40, 1981.

BERRY, L.L and PARASURAMAN, A. Services marketing starts from within, In: R.J. Varey and B.R. Lewis (Eds.), Internal marketing: directions for management. London: Routledge, 2000.

BIBERMAN, J. and WHITTY, M. "A postmodern spiritual future for work". Journal of Organizational Change Management, vol. 10, no. 2, pp. 130-138, 1997

BOYLE, M.V. and HEALY, J. "Balancing mysterium and onus: doing spiritual work within an emotional-laden organizational context". Organization, vol. 10, no. 2, pp. 351-373, 2003.

BUCHHOLZ, R.A. and ROSENTHAL, S. Spirituality, consumption, and business: a pragmatic perspective, In: R.A. Giacalone and C.L Jurkiewicz (Eds.), Handbook of workplace spirituality and organizational performance. Armonk: M. E. Sharpe, 2003.

CACCIOPE, R. "Creating spirit at work: re-visioning organization development and leadership - Part 1". Leadership \& Organization Development Journal, vol. 21, no. 1, pp. 48-54, 2000.

CALAHORRA, A.M.L. Práticas de marketing desenvolvidas pelas empresas, tendo como enfoque o conceito de marketing societal. Unpublished MSc Dissertation, University of São Paulo, São Paulo, 1993.

CARROLL, A.B. "A three-dimensional conceptual model of corporate social performance". Academy of Management Review, vol. 4, no. 4, pp. 497-505, 1979.

CARROLL, A.B. "the pyramid of corporate social responsibility: toward the moral management of organizational stakeholders". Business horizons, VOL. 34, NO. 4, PP. 39-48, 1991.

CARROLL, A.B. “Corporate social responsibility”. Business and Society, vol. 38, no. 3, pp. 268-295, 1999. 
CAVANAGH, G.F. and BANDSUCH, M.R. "Virtue as a benchmark for spirituality in business". Journal of Business Ethics, vol. 38, no. 1/2, pp. 109-117, 2002.

CAVANAGH, G., HANSON, B., HANSON, K., and HINOJOSO J. Toward a spirituality for the contemporary organization: implications for work, family, and society, In: M.L. Pava and P. Primeaux (Eds.), Spiritual intelligence at work: meaning, metaphor, and morals. Research in ethical issues in organizations, vol. 5. Oxford: Elsevier Ltd., 2004

CHATTANANON, A., LAWLEY, M., TRIMETSOONTORN, J., SUPPARERKCHAISAKUL, N., and LEELAYOUTHAYOTHIN, L. "Building corporate image through societal marketing programs". Society and Business Review, vol. 2, no. 3, pp. 230253, 2007

COHEN, J. "Appreciating, understanding, and applying universal moral principles". Journal of Consumer Marketing, vol. 18, no. 7, pp. 578-594, 2001.

COLLINS, M. Posit-ive and negative aspects of the societal marketing concept: stakeholder conflicts for the tobacco industries. Working Paper - WPC 93/13, The Birmingham Business School, 1993.

CRANE, A. and DESMOND, J. "Societal marketing and morality". European Journal of Marketing, vol. 36, no. 5/6, pp. 548-569, 2002.

CZAPLEWSKI, A.J., FERGUSON, J.M., and MILLIMAN, J.F. "Southwest Airlines: how internal marketing pilots success". Marketing Management, vol. 3, no. 3, pp. 14-17, 2001.

D’ANGELO, A.C. "A ética no marketing”. Revista de Administração Contemporânea, vol. 7, no. 4, pp. 55-75, 2003.

DEHLER, G.E. and WELSH, M.A. The experience of work: spirituality and the new workplace, In: R.A. Giacalone and C.L Jurkiewicz (Eds.), Handbook of workplace spirituality and organizational performance. Armonk: M. E. Sharpe, 2003.

DENT, E.B., HIGGINS, M.E., and WHARFF, D.M. "Spirituality and leadership: an empirical review of definitions, distinctions, and embedded assumptions". The Leadership Quarterly, vol. 16, no. 5, pp. 625-653, 2005.

DOS SANTOS, M.A.O. "achieving sustainable competitive advantage through the implementation of the societal marketing concept by a major retailer in south africa". Journal of global business and technology, VOL. 5, NO. 2, PP. 39-50, 2009.

DRUCKER, P.F. “Management's new paradigms”. Forbes, vol. 162, no. 7(October 5), pp. 152-177, 1998.

DRUMWRIGHT, M.E. "Socially responsible organizational buying: environmental concern as a noneconomic buying criteria". Journal of Marketing, vol. 58, no. 3, pp. 1-19, 1994

DRUMWRIGHT, M.E. "Company advertising with a social dimension: the role of noneconomic criteria". Journal of Marketing, vol. 60, no. 4, pp. 71-87, 1996.

EISLER, R. and MONTUORI, A. The human side of spirituality, In: R.A. Giacalone and C.L Jurkiewicz (Eds.), Handbook of workplace spirituality and organizational performance. Armonk: M. E. Sharpe, 2003.

ELM, D.R. Honesty, spirituality and performance at work, In: R.A. Giacalone and C.L Jurkiewicz (Eds.), Handbook of workplace spirituality and organizational performance. Armonk: M. E. Sharpe, 2003.

FLIPO, J-P. Effectiveness implies leaving myths aside, In: R.J. Varey and B.R. Lewis (Eds.), Internal marketing: directions for management. London: Routledge, 2000.

FRAGA, O. "O problema é o rótulo”. Exame, vol. 957, 2 de dezembro, pp. 72-74, 2009.

GARCIA-ZAMOR, J-C. "Workplace spirituality and organizational performance". Public Administration Review, vol. 63, no. 3, pp. 355-363, 2003a.

GARCIA-ZAMOR, J-C. Workplace spirituality in the United States and former East Germany, In: R.A. Giacalone and C.L Jurkiewicz (Eds.), Handbook of workplace spirituality and organizational performance. Armonk: M. E. Sharpe, 2003b.

GAVIN, J.H. and MASON, R.O. "The virtuous organizations: the value of happiness in the Workplace. Organizational Dynamics, vol. 33, no. 4, pp. 379-392, 2004

GIACALONE, R.A. and JURKIEWICZ, C.L. Toward a science of workplace spirituality, In: R.A. Giacalone and C.L Jurkiewicz (Eds.), Handbook of workplace spirituality and organizational performance. Armonk: M. E. Sharpe, 2003.

GIACOMINI FILHO, G. "Uma abordagem societal do marketing e publicidade”. Comunicação e Sociedade, vol. 11, no. 19, pp. 103-114, 1993

GIOIA, D.A. "Business organization as instrument of societal responsibility". Organization, vol. 10, no. 3, pp. 435-438, 2003.

GOZDZ, K. "Toward transpersonal learning communities in business". The American Behavioral Scientist, vol. 43, no. 8, pp. 1262-1285, 2000.

GRANGEIA, M. “O regime do McDonald's”. Exame, vol. 787, 12 de março, p. 14. 2003. 
GUILLORY, W.A. The Living organization: spirituality in the workplace, $2^{\text {nd }}$ Edition, Salt Lake City: Innovations International, 2001.

GULL, G.A. and DOH, J. "The 'transmutation' of the organization: toward a more spiritual workplace". Journal of Management Inquiry, vol. 13, no. 2, pp. 128-139, 2004.

HANDELMAN, J.M. and ARNOLD, S.J. The role of marketing actions with a social dimension: appeals to the institutional environment. Journal of Marketing, vol. 63, no. 3, pp. 33-48, 1999.

HANDY C. The hungry spirit: beyond capitalism: a quest for purpose in the modern world, New York: Broadway Books, 1998.

HEATON, D.P., SCHMIDT-WILK, J., and TRAVIS, F. "Constructs, methods, and measures for researching spirituality in organizations". Journal of Organizational Change Management, vol. 17, no. 1, pp. 62-82, 2004.

HOWARD, S. "A spiritual perspective on learning in the workplace". Journal of Managerial Psychology, vol. 17, no. 3, pp. 230-242, 2002.

HUNT, S.D., WOOD, V.R., and CHONKO, L.B. "Corporate ethical values and organizational commitment in marketing". Journal of Marketing, vol. 53, no. 3, pp. 79-90, 1989.

INGERSOLL, R.E. Spiritual wellness in the workplace, In: R.A. Giacalone and C.L Jurkiewicz (Eds.), Handbook of workplace spirituality and organizational performance. Armonk: M. E. Sharpe, 2003.

JACKSON, K.T. "Spirituality as a foundation for freedom and creative imagination in international business ethics". Journal of Business Ethics, vol. 19, no. 1, pp. 61-70, 1999.

JUDD, V.C. "Achieving a customer orientation using 'people-power', the '5th P". European Journal of Marketing, vol. 37, no. 10 , pp. 1301-1313, 2003.

JURKIEWICZ, C.L. and GIACALONE, R.A. "A values framework for measuring the impact of workplace spirituality on organizational performance". Journal of Business Ethics, vol. 49, no. 2, pp. 129-142, 2004.

KANG, G.D. and JAMES, J. "Revisiting the concept of a societal orientation: conceptualization and delineation". Journal of Business Ethics, vol. 73, no. 3, pp. 301-318, 2007.

KING, S. and NICOL, D.M. "Organizational enhancement through recognition of individual spirituality: reflections of Jaques and Jung". Journal of Organizational Change Management, vol. 12, no. 3, pp. 234-243, 1999.

KOMALA, K. and GANESH, L.S. "Individual spirituality at work and its relationship with job satisfaction and burnout: an exploratory study among healthcare professionals". The Business Review 1 vol. 7, no. 1, pp. 124-129, 2007.

KOTLER, P. "What consumerism means for marketers”. Harvard Business Review, vol. 50, no. 3, pp. 48-57, 1972.

KOTLER, P. Marketing management: analysis, planning, implementation, and control, $\mathbf{9}^{\text {th }}$ edition, Upper Saddle River: Prentice Hall, 1997.

KOTLER, P. and ARMSTRONG, G. Princípios de marketing, 9ª edição, São Paulo: Prentice Hall, 2003.

KRISHNAKUMAR, S. and NECK, C.P. "The 'what', 'why' and 'how' of spirituality in the workplace”. Journal of Managerial Psychology, vol. 17, no. 3, pp. 153-164, 2002.

LEE, D.-J. and SIRGY, M.J. "Quality-of-life (QOL) marketing: proposed antecedents and consequences". Journal of Macromarketing, vol. 24, no. 1, pp. 44-58, 2004.

LENNICK, D. and KIEL, F. Moral intelligence: enhancing business performance and leadership success, Upper Saddle River: Wharton School Publishing, 2005.

MAIGNAN, I., FERRELL, O.C., and HULT, G.T.M. "Corporate citizenship: cultural antecedents and business benefits". Journal of the Academy of Marketing Science, vol. 27, no. 4, pp. 455-469, 1999.

MAIGNAN, I. and FERRELL, O.C. "Corporate citizenship as a marketing instrument: concepts, evidence, and research directions". European Journal of Marketing, vol. 35, no. 3/4, pp. 457-484, 2001.

MAIGNAN, I. and FERRELL, O.C. "Corporate social responsibility and marketing: an integrative framework". Journal of the Academy of Marketing Science, vol. 32, no. 1, pp. 3-19, 2004.

MCALISTER, D.T. and FERRELL, L. "The role of strategic philanthropy in marketing strategy". European Journal of Marketing, vol. 36, no. 5/6, pp. 689-705, 2002.

MCKEE, D. Spirituality and marketing: an overview of the literature, In: R.A. Giacalone and C.L Jurkiewicz (Eds.), Handbook of workplace spirituality and organizational performance. Armonk: M. E. Sharpe, 2003.

MENDES, L., VIEIRA, F.G.D., and CHAVES, C.J.A. "Responsabilidade social e isomorfismo organizacional: o paradoxo de ações (anti)éticas em busca de legitimidade no mercado brasileiro”. Revista Gestão.Org, vol. 7, no. 2, pp. 192-212, 2009. 
MILES, M.P. and WHITE, J.B. "Commentary: setting irresponsible marketing objectives: a comment on a "quality of life approach". European Journal of Marketing, vol. 32, no. 5/6, pp. 413-418, 1998.

MITROFF, I.I. Spirituality at work: the next major challenge in management, In T.C. Pauchant (Ed.), Ethics and spirituality at work: hopes and pitfalls of the search for meaning in organizations. Wesport: Quorum Books, 2002.

MITROFF, I.I. Business not as usual: reflections on spirituality in the workplace, In O.F. Willians (Ed.), Business, religion, and spirituality: a new synthesis. Notre Dame: University of Notre Dame Press, 2003.

MOORE, T.W. and CASPER, W.J. "An examination of proxy measures of workplace spirituality: A profile model of multidimensional constructs". Journal of Leadership \& Organizational Studies, vol. 12, no. 4, pp. 109-118, 2006.

MOXLEY, R.S. Leadership \& spirit: breathing new vitality and energy into individuals and organizations, San Francisco: Jossey-Bass, 2000.

MUDIE, P. "Internal customer: by design or by default". European Journal of Marketing, vol. 37, no. 9, pp. 1261-1276, 2003.

MURPHY, P.E. Marketing ethics at the new millennium: review, reflections and recommendations. Available at: http://www.nd.edu/ ethbus/research/Marketing Ethics Millenium (Accessed on April 6, 2004).

NEAL J. "Work as service to the divine: giving your gifts selflessly and with enjoy". The American Behavior Scientist, vol. 43, no. 8, pp. 1316-1333, 2000.

PARBOTEEAH, K.P. and CULLEN, J.B. Ethical climates and spirituality: an exploratory examination of theoretical links, In: R.A. Giacalone and C.L Jurkiewicz (Eds.), Handbook of workplace spirituality and organizational performance. Armonk: M. E. Sharpe, 2003.

PAUCHANT, T.C. Introduction: ethical and spiritual management addresses the need for meaning in the workplace, In T.C. Pauchant (Ed.). Ethics and spirituality at work: hopes and pitfalls of the search for meaning in organizations. Wesport: Quorum Books, 2002.

PFEFFER, J. Business and the spirit: management practices that sustain values, In: R.A. Giacalone and C.L Jurkiewicz (Eds.), Handbook of workplace spirituality and organizational performance. Armonk: M. E. Sharpe, 2003.

PFEFFER, J. and VEIGA, J.F. "Putting people first for organizational success". Academy of Management Executive, vol. 13, no. 2, pp. 37-48, 1999.

RAFIQ, M. and AHMED, P.K. "Advances in the internal marketing concept: definition, synthesis and extension". The Journal of Services Marketing, vol. 14, no. 6, pp. 449-463, 2000.

ROSENBLUTH, H.F. and PETERS, D.M. Good company: caring as fiercely as you compete, Massachusetts: Perseus Books, 1998

ROSENTHAL, S. and BUCHHOLZ, R. The spiritual corporation: a pragmatic perspective, In M.L. Pava and P. Primeaux (Eds.). In: M.L. Pava and P. Primeaux (Eds.), Spiritual intelligence at work: meaning, metaphor, and morals. Research in ethical issues in organizations, vol. 5. Oxford: Elsevier Ltd., 2004

SASS, J.S. "Characterizing organizational spirituality: an organizational communication culture approach". Communication Studies, vol. 51, no. 3, pp. 195-217, 2000.

SHEEP, M.L. "Nurturing the whole person: the ethics of workplace spirituality in a society of organizations". Journal of Business Ethics, vol. 66, no. 4, pp. 357-375, 2006

SINGHAPAKDI, A., KARANDE, K., RAO, C.P., and VITELL, S.J. "How important are ethics and social responsibility? - A multinational study of marketing professionals". European Journal of Marketing, vol. 35, no. 1/2, pp. 133-153, 2001.

SIRGY, M.J. "Strategic marketing planning concept guided by the quality-of-life (QOL) concept". Journal of Business Ethics, vol. 15, no. 3, pp. 241-259, 1996

SIROTA, D., MISCHKIND, L.A., and MELTZER, M.I. The enthusiastic employee: how companies profit by giving workers what they want, Upper Saddle River: Wharton School Publishing, 2005.

SMITH N.C. "Marketing strategies for the ethics era". Sloan Management Review, vol. 36, no. 4, pp. 85-97, 1995.

STEIN, M.A. "Corporations tidy up as the year ticks away". The New York Times. Available at: http://www.nytimes.com/2005/12/24/business/24five.ready.html. (Accessed on December 24, 2005).

STRAUGHAN, R.D. and ROBERTS, J.A. "An environmental segmentation alternatives: a look at green consumer behavior in the new millennium". Journal of Consumer Marketing, vol. 16, no. 6, pp. 558-575, 1999.

TAKAS, A. "Societal marketing: a businessman's perspective". Journal of Marketing, vol. 38, no. 4, pp. 2-7, 1974

TISCHLER, L. "The growing interest in spirituality in business: a long-term socio-economic explanation". Journal of Organizational Change Management, vol. 12, no. 4, pp. 272-280, 1999. 
TROTT, D.C. Spiritual well-being of workers: an exploratory study of spirituality in the workplace. Unpublished Doctoral Dissertation, The University of Texas, Austin, 1996.

VARADARAJAN, P.R. and MENON, A. "Cause-related marketing: a coalignment of marketing strategy and corporate philanthropy". Journal of Marketing, vol. 52, no. 3, pp. 58-74, 1988.

VASCONCELOS A.F. "Broadening even more the internal marketing concept". European Journal of Marketing, vol. 42, np. 11/12, pp. 1246-1264, 2008.

WAGNER-MARSH, F. and CONLEY, J. "The fourth wave: the spiritually-based firm". Journal of Organizational Change Management, vol. 12, no. 4, pp. 292-301, 1999.

WARD, S. and LEWANDOWSKA, A. "Shelter in the storm: marketing strategy as moderated by the hostile environment". Marketing Intelligence \& Planning, vol. 23, no. 6/7, pp. 670-687, 2005.

WARD, S. and LEWANDOWSKA, A. "Is the marketing concept always necessary? The effectiveness of customer, competitor and societal strategies in business environment types". European Journal of Marketing, vol. 42, no. 1/2, pp. 222-237, 2008.

WRZESNIEWSKI, A. Finding a positive meaning in work, In K.S. Cameron, J. E. Dutton, and R.E. Quinn (Eds.), Positive organizational scholarship: foundations of a new discipline. San Francisco: Berret-Koelher, 2003. 